\title{
PENGARUH KOMPETENSI DAN BUDAYA KERJA TERHADAP PERSON JOB FIT DAN KINERJA KARYAWAN PADA PT ANDROMEDIA
}

\author{
Lutfiyah \\ Sekolah Tinggi Ilmu Ekonomi Indonesia (STIESIA) Surabaya \\ lutfiyahsurabaya@gmail.com \\ Hening Widi Oetomo \\ Sekolah Tinggi Ilmu Ekonomi Indonesia (STIESIA) \\ heningwidio@stiesia.ac.id \\ Suhermin \\ Sekolah Tinggi Ilmu Ekonomi Indonesia (STIESIA) Surabaya \\ $\underline{\text { suhermin@stiesia.ac.id }}$
}

\begin{abstract}
PT Andromedia is a private company engaged in IT Development located at Jalan Gayung Kebonsari Perum Graha Indah F21-22 Surabaya. This study aims to analyze the influence of competence and work culture on person-job fit and employee performance at PT Andromedia. The population in this study amounted to 68 employees and the sampling technique used was saturated sampling meaning that the entire population would be sampled. The tool for analyzing data in this study uses the Partial Least Square (PLS) analysis method that is run with SmartPLS 3.0 software. The test results have 5 hypotheses, among others, first, competence has no significant effect on a person-job fit. Second, work culture has a significant influence on a person-job fit. Third, competence has a non-significant effect on employee performance. Fourth, work culture has a significant effect on employee performance. Fifth, the person-job fit has a significant influence on employee performance.
\end{abstract}

Keywords: competence; employee performance; person job fit; work culture.

\section{PENDAHULUAN}

Kinerja karyawan merupakan aspek penting dalam kesuksesan sebuah perusahaan secara keseluruhan di mana pemilik bisnis membutuhkan karyawan yang mampu menyelesaikan pekerjaan secara efektif. Para manajer perusahaan tentu perlu memahami manfaat utama dari kinerja karyawan dan hal yang memengaruhinya guna menentukan kekuatan, kelemahan, dan potensi celah manajerial dalam organisasi bisnis (Sysindo, 2018). Berdasarkan hasil wawancara, ini yang diharapkan oleh setiap perusahaan terutama perusahaan baru dalam fase berkembang atau yang dikenal start-up, salah satunya PT Andromedia yang menyatakan faktor terpenting dalam kinerja karyawan adalah mencapai tujuan dan bekerja secara efektif menyelesaikan pekerjaan dengan benar dan berhasil memenuhi deadline pekerjaan. Faktor penting lainnya adalah menumbuhkan lingkungan kerja yang positif dan energik dengan saling memberikan semangat di tempat kerja, misal menciptakan lingkungan kerja yang positif dengan memberi penghargaan kepada karyawan yang memiliki kinerja tinggi.

Menurut Kasmir (2016:182), kinerja adalah hasil kerja dan perilaku kerja yang telah dicapai dalam menyelesaikan tugas-tugas dan tanggung jawab yang diberikan dalam suatu periode tertentu. Berdasarkan pengertian tersebut, kinerja adalah kemampuan seseorang untuk melaksanakan tugastugasnya, dan kinerja dapat diukur dari kemampuan karyawan untuk menyelesaikan tugas-tugas sesuai dengan standar perusahaan. PT Andromedia tiap karyawan dituntut untuk dapat meningkatkan kinerja guna menyelesaikan pekerjaan sesuai deadline. Dalam meningkatkan kinerja karyawan terdapat beberapa hal yang memengaruhinya seperti tersedianya fasilitas yang menunjang pekerjaan, budaya kerja untuk menciptakan lingkungan kerja yang positif, pengembangan diri untuk lebih berkompeten, penghargaan atau bonus insentif yang diberikan kepada karyawan yang berprestasi. 
Tabel 1.

JUMLAH KARYAWAN DAN PENYELESAIAN PROJECT PT ANDROMEDIA TH. 2017

\begin{tabular}{ccc}
\hline Bulan & Karyawan & Project \\
\hline Januari & 47 & 3 \\
Februari & 47 & 3 \\
Maret & 49 & 4 \\
April & 50 & 5 \\
Mei & 50 & 4 \\
Juni & 50 & 5 \\
Juli & 57 & 2 \\
Agustus & 57 & 6 \\
September & 56 & 5 \\
Oktober & 48 & 4 \\
Nopember & 50 & 3 \\
Desember & 51 & 3 \\
Total & 612 & 47 \\
Rata - rata & 51 & 3.9 \\
\hline
\end{tabular}

Sumber : Data Administrator (2017)

Penilaian kinerja karyawan pada PT Andromedia saat ini dinilai dari jumlah karyawan dan total project yang dapat diselesaikan pada periode tertentu. Penilaian tersebut dapat dikatakan baik di mana dengan banyaknya jumlah karyawan menghasilkan bertambahnya jumlah project yang terselesaikan. Tabel 1 menunjukkan bahwa jumlah karyawan dan project PT Andromedia dari bulan Januari 2017 - Desember 2017 mengalami fluktuatif. Menurut informasi dari HRD terdapat beberapa kemungkinan salah satunya ada pembaruan modul yang diminta oleh klien PT Andromedia, namun kemungkinan tersebut tidak dapat dijadikan alasan khusus karena setiap karyawan harus siap bekerja dibawah tekanan. Informasi dari HRD tersebut dapat diasumsikan bahwasannya terdapat gap antara kemampuan kompetensi yang dimiliki oleh karyawan dengan kinerja yang dihasilkan.

Merujuk dari permasalahan tersebut, dalam meningkatkan kinerja karyawan ada hal yang memengaruhi yaitu person job fit, kompetensi, dan budaya kerja. Menurut Rogelberg (2012), person job fit dapat didefinisikan sebagai kompatibilitas antara individu dan pekerjaan atau tugas yang mereka lakukan ditempat kerja. Definisi ini mencakup kompatibilitas berdasarkan kebutuhan karyawan dan perlengkapan pekerjaan yang tersedia untuk memenuhi kebutuhan tersebut serta tuntutan pekerjaan dan kemampuan karyawan untuk memenuhi permintaan tersebut. Data jumlah karyawan dan project yang cenderung menurun dalam penyelesaiannnya menunjukkan bahwa selama ini person job fit terhadap kinerja karyawan pada PT Andromedia masih dianggap rendah. Hasil penelitian dari Wahjudhy (2014) menunjukkan bahwa person job fit memiliki pengaruh yang signifikan dan positif terhadap kinerja karyawan. Hal ini senada juga dikemukan oleh Abila (2015) bahwa person job fit berpengaruh positif dan signifikan terhadap kinerja karyawan.

Menurut Wibowo (2016:271), kompetensi adalah suatu kemampuan untuk melaksanakan atau melakukan suatu pekerjaan atau tugas yang dilandasi atas keterampilan dan pengetahuan serta didukung oleh sikap kerja yang dituntut oleh pekerjaan tersebut. Kompetensi sebagai kemampuan seseorang untuk menghasilkan pada tingkat yang memuaskan di tempat kerja, termasuk di antaranya kemampuan seseorang untuk mentransfer dan mengaplikasikan keterampilan dan pengetahuan tersebut dalam situasi yang baru dan meningkatkan manfaat yang disepakati. Kompetensi juga menunjukkan karakteristik pengetahun dan keterampilan yang dimiliki atau dibutuhkan oleh setiap individu yang memampukan mereka untuk melakukan tugas dan tanggung jawab mereka secara efektif dan meningkatan standar kualitas profesionalisme dalam pekerjaan mereka. Hasil penelitian dari Suliman (2011) menunjukkan bahwa kompetensi memiliki pengaruh yang signifikan dan positif terhadap kinerja karyawan. Hal ini senada juga dikemukan oleh Abila (2015) bahwa kompetensi berpengaruh positif dan signifikan terhadap kinerja karyawan. Berbeda dengan hasil penelitian Widyasmoko (dalam Rahayuningsih dan 
Lutfiyah, Hening Widi Oetomo, Suhermin. Pengaruh Kompetensi dan Budaya Kerja terhadap Person Job Fit dan Kinerja Karyawan pada PT Andromedia

Maelani, 2017) menunjukkan bahawa kompetensi berpengaruh tidak signifikan terhadap kinerja karyawan.

Menurut Schein (dalam Frinaldi, 2014), budaya kerja pegawai adalah perspektif nilai, pemahaman cara bekerja, aturan, norma, pola pikir, dan perilaku setiap seseorang pegawai atau sekelompok pegawai maupun pimpinannya dalam menjalankan suatu pekerjaan. Karyawan pada PT Andromedia harus mampu beradaptasi dengan budaya selain berkompeten, secara alamiah meningkatnya kinerja karyawan dan person job fit itu dapat dipengaruhi langsung oleh budaya kerja yang positif dan energik dengan saling memberikan semangat di tempat kerja.

Penelitian dari Safrizal et al (2014) menunjukkan bahwa budaya kerja berpengaruh secara parsial dan simultan terhadap kinerja karyawan. Hal ini sejalan dengan hasil penelitian dari Jamaluddin et al (2017) menunjukkan bahwa budaya kerja berpengaruh signifikan terhadap kinerja karyawan. Berbeda dengan hasil penelitian Arifin (2010) menunjukkan bahawa budaya kerja berpengaruh tidak signifikan terhadap kinerja karyawan.

Berdasarkan latar belakang masalah, rumusan masalah penelitian ini adalah sebagai berikut. (1) Apakah kompetensi berpengaruh terhadap person job fit? (2) Apakah budaya kerja berpengaruh terhadap person job fit? (3) Apakah kompetensi berpengaruh terhadap kinerja karyawan? (3) Apakah budaya kerja berpengaruh terhadap kinerja karyawan? (4) Apakah person job fit berpengaruh terhadap kinerja karyawan?

\section{KAJIAN PUSTAKA DAN PENGEMBANGAN HIPOTESIS}

\section{Kompetensi}

Menurut Spencer (dalam Moeheriono, 2014:5), kompetensi merupakan karakteristik yang mendasari seseorang berkaitan dengan efektivitas kinerja individu dalam pekerjaannya atau karakteristik dasar individu yang memiliki hubungan kausal atau sebagai sebab-akibat dengan kriteria yang dijadikan acuan, efektif atau berkinerja prima atau superior ditempat kerja. Boyatzis menyebutkan (dalam Priansa, 2014:253) bahwa kompetensi adalah kapasitas yang ada pada seseorang yang bisa membuat orang tersebut mampu memenuhi apa yang diisyaratkan oleh pekerjaan dalam suatu organisasi sehingga organisasi tersebut mampu mencapai hasil yang diharapkan.

Dalam penelitian ini, variabel kompetensi yang akan digunakan untuk mengukur kompetensi menurut Gordon (dalam Sutrisno, 2011:204) sebagai berikut. (1) Pengetahuan (knowledge). Pengetahuan merupakan pengetahuan atau informasi seseorang dalam bidang spesifik tertentu. Indikator pada dimensi pengetahuan adalah Pendidikan, pengalaman kerja, dan minat. (2) Kemampuan/ ketrampilan (skills). Kemampuan/ ketrampilan (skills) adalah kemampuan untuk melaksanakan tugas fisik tertentu atau tugas mental tertentu. Indikator pada dimensi kemampuan/ketrampilan adalah kemampuan intelektual dan kemampuan fisik.

\section{Budaya Kerja}

Schein (dalam Frinaldi, 2014) menyebutkan bahwa budaya kerja pegawai adalah perspektif nilai, pemahaman cara bekerja, aturan, norma, pola pikir, dan perilaku setiap seseorang pegawai atau sekelompok pegawai maupun pimpinannya dalam menjalankan suatu pekerjaan. Budaya kerja sudah lama dikenal oleh manusia, namun belum disadari bahwa suatu keberhasilan kerja berakar pada nilainilai yang dimiliki dan perilaku yang menjadi kebiasaan. Nilai-nilai tersebut bermula dari adat istiadat, agama, norma dan kaidah yang menjadi keyakinan pada diri pelaku kerja atau organisai. Nilai-nilai yang menjadi kebiasaan tersebut dinamakan budaya dan mengingat hal ini dikaitkan dengan mutu kerja, maka dinamakan budaya kerja (Nurhadijah, 2017). Paramita (dalam Amin, 2017) mengatakan bahwa untuk mengukur indikator budaya kerja adalah mau menerima arahan pimpinan, senang menerima tanggung jawab kerja, kerja sebagai ibadah, melaksanakan pekerjaan sesuai tugas, dapat mengatasi kendala kerja, dapat menyusun laporan kerja, disiplin kerja, jujur dalam kerja, komitmen kerja, tanggungjawab terhadap pekerjaan, kerjasama dengan rekan kerja, dan mengevaluasi pekerjaan. 


\section{Person-Job Fit}

Teori kesesuaian kepribadian-pekerjaan (person job-fit) adalah milik dari John Holland, teori ini didasarkan dari kesesuaian karyawan dengan pekerjaanya. Holland dalam penelitiannya menyatakan bahwa ketika kepribadian dan pekerjaan sangat cocok maka akan memunculkan kepuasan dalam diri karyawan meningkat. Seperti contohnya orang yang realistis berada dalam situasi yang realistis lebih sesuai dari pada orang yang realistis berada dalam situasi yang konvensional (Robbin dan Judge, 2008).

Person-job fit diartikan sebagai cocoknya kemampuan dari individu dengan tuntutan dari sebuah pekerjaan. Person-job fit didefinisikan sebagai kompatibilitas antara individu dan pekerjaan atau tugas yang mereka lakukan di tempat kerja. Definisi ini mencakup kompatibilitas (kemampuan) berdasarkan kebutuhan karyawan dan perlengkapan pekerjaan yang tersedia untuk memenuhi kebutuhan tersebut, serta tuntutan pekerjaan dan kemampuan karyawan untuk memenuhi permintaan tersebut (Cable dan DeRue, 2002).

Person-job fit dikaji dengan menetapkan pekerjaan yang dibutuhkan sesuai dengan analisis pekerjaan yang telah ditetapkan oleh pihak yang berwenang dalam organisasi sehingga bakat, pengetahuan dan kemampuan pekerja sesuai dengan tuntutan pekerjaan. Berdasarkan psikologi interaksional, premis yang mendasari person-job fit adalah bahwa karakteristik pribadi dan pekerjaan kerja bersama untuk menentukan hasil individual (Farzaneh et al., 2014).

Ketidaksesuaian antara kompetensi dengan tugas pekerjaan yang diberikan dapat memberikan efek ketidakpuasan yang tinggi diantara pada karyawan (Christiansen et al, 2014). Dampaknya karyawan akan memiliki tingkat stres yang tinggi karena ketidakpuasannya dan akan membuat karyawan tersebut cenderung meninggalkan pekerjaannya (Mahdi et al, 2012).

Kristof et al. (2005) menyatakan bahwa mengukur indikator person job fit adalah sebagai berikut. (1) Kecocokan antara pekerjaan dengan kemampuan. (2) Kecocokan antara pekerjaan dengan pengetahuan. (3) Kepuasan pribadi dengan pekerjaan tersebut. (4) Keinginan dari individu cocok denga karakteristik pekerjaan.

\section{Kinerja Karyawan}

Kinerja menurut Fahmi (2014) adalah hasil yang diperoleh oleh suatu organisasi baik organisasi tersebut bersifat profit oriented dan non profit oriented yang dihasilkan selama satu periode waktu. Kinerja perusahaan sangat ditentukan oleh kinerja sumber daya manusia yang dimilikinya. Untuk itu perusahaan harus mampu mengembangkan berbagai faktor keberhasilan pelaksanaan perusahaan yang dikontribusikan oleh keandalan sumber daya manusianya (karyawan).

Menurut Kasmir (2016:182), "Kinerja adalah hasil kerja dan perilaku kerja yang telah dicapai dalam menyelesaikan tugas-tugas dan tanggung jawab yang diberikan dalam suatu periode tertentu." Berdasarkan pengertian di atas, kinerja adalah kemampuan seseorang untuk melaksanakan tugastugasnya, dan kinerja dapat diukur dari kemampuan karyawan untuk menyelesaikan tugas-tugas sesuai dengan standar perusahaan

Oleh karena itu, kinerja karyawan merupakan aspek penting dalam kesuksesan sebuah perusahaan secara keseluruhan di mana pemilik bisnis membutuhkan karyawan yang mampu menyelesaikan pekerjaan secara efektif. Para manajer perusahaan tentu perlu memahami manfaat utama dari kinerja karyawan dan hal yang memengaruhinya guna menentukan kekuatan, kelemahan, dan potensi celah manajerial dalam organisasi bisnis (Sysindo, 2018).

Menurut Mangkunegara (2014) terdapat dua aspek atau dimensi standar kinerja karyawan, dan kemudian dikembangkan menjadi beberapa indikator, antara lain sebagai berikut. (1) Kuantitatif, indikatornya meliputi proses kerja dan kondisi pekerjaan, waktu dalam bekerja, jumlah kesalahan, serta 
Lutfiyah, Hening Widi Oetomo, Suhermin. Pengaruh Kompetensi dan Budaya Kerja terhadap Person Job Fit dan Kinerja Karyawan pada PT Andromedia

jumlah dan jenis pekerjaan. (2) Kualitatif, indikatornya meliputi kualitas pekerjaan, ketepatan waktu, kemampuan dan ketrampilan bekerja, serta kemampuan mengevaluasi.

\section{Hubungan antar Variabel}

Kompentensi dapat mempuyai peranan yang sangat penting bagi kesuksesan sebuah perusahaan dalam bidang sumber daya manusia (Prayitno dan Andrilina, 2015). Maka diperlukan kompentensi yang meningkatkan kinerja karyawan. PT Andromedia adalah perusahaan yang bergerak di bidang jasa konsultan IT yang mana perkembangan teknologi yang semakin canggih mengharuskan karyawan untuk berkompeten dan dapat menyesuaikan kecocokan dirinya dengan tim kerja (Person job fit) sesuai beban pekerjaan yang akan dikerjakan.

Penelitian terdahulu tentang hubungan variabel kompetensi terhadap person job fit ini belum pernah diteliti, namun secara teoritis kompetensi mempunyai hubungan terhadap person job fit yang mana kecocokan seorang karyawan dengan pekerjaaanya dapat dipengaruhi oleh kompetensi yang dimiliki oleh tiap karyawan. Definisi ini mencakup kompatibilitas (kemampuan) berdasarkan kebutuhan karyawan dan perlengkapan pekerjaan yang tersedia untuk memenuhi kebutuhan tersebut, serta tuntutan pekerjaan dan kemampuan karyawan untuk memenuhi permintaan tersebut (Cable dan DeRue, 2002). Pendapat lain dari Widyaastuti dan Ratnaningsih (2018) menjelaskan adanya hubungan kompetensi dan person job fit dilihat dari aspek pendidikan. Pada person job fit, pendidikan merupakan salah satu bentuk dari aspek pengetahuan yang juga dapat memengaruhi keahlian serta kemampuan. Ketika ada ketidaksesuaian antara pendidikan dengan pekerjaan yang diberikan, maka artinya tidak ada kesesuaian antara kompetensi individu dengan pekerjaannya.

\section{H1: Kompetensi berpengaruh signifikan terhadap person job fit.}

Budaya kerja merupakan organisasi terbentuk sejak satuan kerja atau organisasi tersebut berdiri (Tridharma, 2017). Hampir sama dengan yang ada pada PT Andromedia setiap proyek yang dikerjakan merupakan kerja tim yang dilakukan oleh beberapa karyawa. Oleh sebab itu karyawan pada PT Andromedia diharapkan siap untuk bekerja sama atau kecocokan antar individual pada pekerjaan.

Penelitian terdahulu tentang hubungan variabel Budaya Kerja terhadap person job fit ini belum pernah diteliti. namun secara teoritis budaya kerja mempunyai hubungan terhadap person job fit yang mana kecocokan seorang karyawan dengan pekerjaaanya dapat dipengaruhi oleh budaya kerja dalam organisasinya. Pendapat dari Supriyadi dan Guno (2011:7) mengemukakan bahwa budaya kerja adalah suatu falsafah dengan didasari pandangan hidup sebagai nilai-nilai yang menjadi sifat, kebiasaan dan juga pendorong yang dibudayakan dalam suatu kelompok dan tercermin dalam sikap menjadi perilaku, cita-cita, pendapat, pandangan serta tindakan yang terwujud sebagai kerja atau bekerja.

Pendapat lain dari Ozag dan Duguma (2005) yang menjelaskan dalam teori person job fit adanya kesesuaian antara karakteristik tugas pekerjaan dengan kebutuhan individu untuk melaksanakan tugas tersebut, akan memperkuat ikatan pegawai pada kerja, yaitu pegawai akan lebih komitmen terhadap pekerjaan sehingga kenyamanaan pada diri karyawan itu muncul. Kenyamanan kerja karyawan dipengaruhi oleh faktor kenyamanan seorang individu tersebut terhadap budaya kerja yang ada di dalam suatu perusahaa. Budaya kerja tersebut adalah lingkungan kerja yang baik dan kondusif yang diciptakan karyawan sehingga memberikan rasa nyaman dalam berkomunikasi pada setiap bagian perusahaan. Peningkatan hubungan antar karyawan pun akan memberikan kepuasan pada sistem kerja yang dijalankan sehingga karyawan mampu untuk mengetahui tindakan apa yang seharusnya dilakukan sesuai dengan nilai-nilai yang ada.

\section{H2: Budaya kerja berpengaruh signifikan terhadap person job fit.}

PT Andromedia membutuhkan karyawan yang berkompeten guna meningkatkan kinerja karyawan. Harapannya setiap karyawan tersebut dapat bersaing dengan menghasilkan aplikasi bernilai lebih dibanding kompetitor. Menurut Grote (dalam Pramudyo, 2010), kompetensi dapat digunakan untuk memprediksi kinerja, yaitu siapa yang berkinerja baik dan kurang baik tergantung pada kompetensi yang dimilikinya, diukur dari kriteria atau standar yang digunakan. 
Mangkunegara dan Waris (2015) menjelaskan tujuan pelatihan, kompetensi dan kedisiplinan karyawan yang bekerja di PT. Askrida Build Insurance. Hasil penelitian menunjukkan bahwa pelatihan, kompetensi dan disiplin kerja bersama memengaruhi kinerja karyawan di PT. Asuransi Membangun Askrida. Hal tersebut akan meningkatkan kinerja karyawan dan pada akhirnya mencapai tujuan perusahaan. Hasil penelitian dari Suliman (2011) menunjukkan bahwa kompetensi memiliki pengaruh yang signifikan dan positif terhadap kinerja karyawan. Hal ini senada juga dikemukan oleh Abila (2015) bahwa kompetensi berpengaruh positif dan signifikan terhadap kinerja karyawan. Berbeda dengan hasil penelitian Widyasmoko (dalam Rahayuningsih dan Maelani, 2017) menunjukkan bahwa kompetensi berpengaruh tidak signifikan terhadap kinerja karyawan.

H3: Kompetensi berpengaruh signifikan terhadap kinerja karyawan.

Budaya kerja merupakan sikap dan perilaku individu dan kelompok yang didasari atas nilai-nilai yang diyakini kebenaranya dan telah menjadi sifat serta kebiasaan dalam melaksanakan tugas dan pekerjaan sehari-hari di perusahaan (Nurhadijah, 2017). Supriyanto dan Machfud (2010) berpendapat bahwa kinerja merupakan suatu hasil dari usaha seseorang yang dicapai dengan adanya kemampuan dan perbuatan dalam situasi tertentu.

Dalam penelitian Lolowang et al (2019), budaya kerja berpengaruh signifikan terhadap kinerja karyawan. Penelitian Safrizal et al (2014) menunjukkan bahwa budaya kerja berpengaruh secara parsial dan simultan terhadap kinerja karyawan. Hal ini sejalan dengan hasil penelitian dari Jamaluddin et al (2017) menunjukkan bahwa budaya kerja berpengaruh signifikan terhadap kinerja karyawan. Berbeda dengan hasil penelitian Arifin (2010) menunjukkan bahawa budaya kerja berpengaruh tidak signifikan terhadap kinerja karyawan. Sedangkan menurut Silvia et al (2016) menyatakan bahwa budaya kerja berpangaruh positif dan signifikan terhadap kinerja karyawan.

H4: Budaya kerja berpengaruh signifikan terhadap kinerja karyawan.

Holland dalam penelitiannya menyatakan bahwa ketika kepribadian dan pekerjaan sangat cocok maka akan memunculkan kepuasan dalam diri karyawan meningkat. Adapun contohnya sama seperti orang yang realistis berada dalam situasi yang realistis lebih sesuai dari pada orang yang realistis berada dalam situasi yang konvensional (Robbins dan Judge, 2008).

Person-job fit diartikan sebagai cocoknya kemampuan dari individu dengan tuntutan dari sebuah pekerjaan. Person-job fit didefinisikan sebagai kompatibilitas antara individu dan pekerjaan atau tugas yang mereka lakukan di tempat kerja (Cable dan DeRue, 2002). June et al (2013) menjelaskan bahwasannya person job fit berpengaruh positif dan signifikan terhadap kinerja karyawan. Hal ini senada dengan yang dipaparkan oleh Wahjudhy (2014) bahwasannya person job fit berpengaruh positif dan signifikan terhadap kinerja karyawan. Hubungan antar variable dalam penelitian ini juga digambarkan di Gambar 1.

H5: Person job fit berpengaruh signifikan terhadap kinerja karyawan.

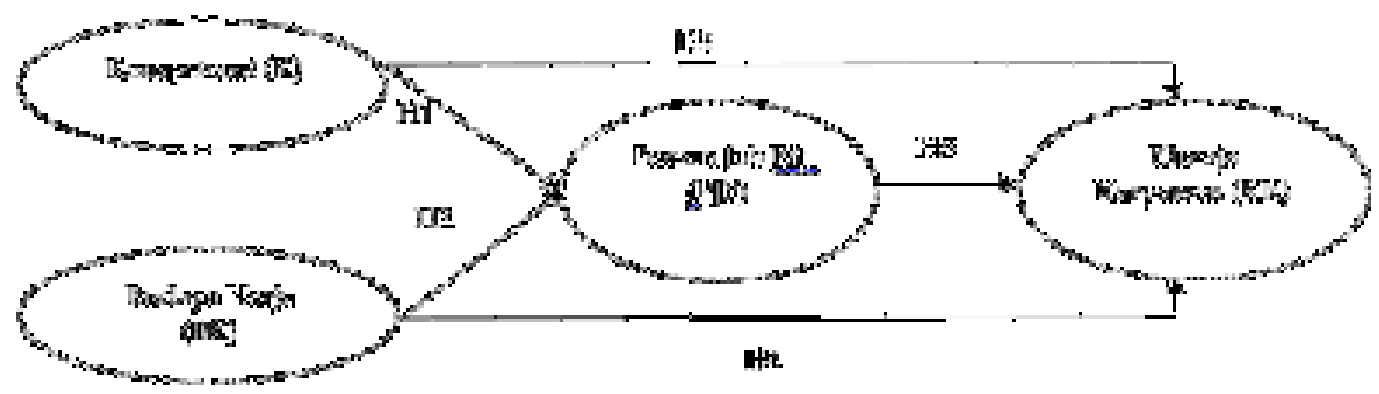

Gambar 1. KERANGKA KONSEPTUAL 
Lutfiyah, Hening Widi Oetomo, Suhermin. Pengaruh Kompetensi dan Budaya Kerja terhadap Person Job Fit dan Kinerja Karyawan pada PT Andromedia

\section{METODE PENELITIAN}

Penelitian ini merupakan penelitian kuantitatif, dan jenis penelitiannya adalah kausal. Populasi dalam penelitian ini adalah karyawan PT Andromedia yang berjumlah dari 68 karyawan. Teknik pengambilan sampel dalam penelitian ini adalah sampling jenuh sehingga sampel dalam penelitian ini adalah seluruh dari populasi yang diambil yang berjumlah 68 dan anggota populasi dianggap homogen. Teknik pengumpulan data menggunakan kuesioner (angket) dengan skala Likert dengan rentang skala 1-5 dengan kriteria sangat tidak setuju, tidak setuju, cukup setuju, setujum dan sangat setuju. Terdapat 2 teknik analisis data dalam penelitian ini di antaranya statistik deskriptif analisis Partial Least Square (PLS).

\section{HASIL DAN PEMBAHASAN}

\section{Hasil Uji Instrumen Penelitian}

Penelitian ini dilakukan uji instrument validitas sebagai pra-penelitian dengan sampel acak sebanyak 30. Pengujian validitas menggunakan ketentuan jika signifikansi dari $r$ hitung atau $r$ hasil $>r$ tabel $(\mathrm{df}$ $=\mathrm{n}-2=0,196)$ maka item variabel disimpulkan valid. Hasil uji validitas data sebagaimana dapat dilihat pada Lampiran 1. Maka dapat diketahui bahwa seluruh item pernyataan mengenai variabel Kompetensi, Budaya Kerja, Person Job Fit, dan Kinerja Karyawan yang berjumlah 29 item, mempunyai nilai $r$ hasil $>$ dari $r$ tabel, dan sesuai dengan ketentuan yang telah ditetapkan, maka hal ini berarti bahwa seluruh item pertanyaan tersebut seluruhnya valid dan dapat digunakan dalam penelitian.

Pengukuran reliabilitas dalam penelitian ini adalah dengan menggunakan cara one shot method atau pengukuran sekali saja. Untuk mengukur reliabilitas dengan melihat cronbach alpha. Suatu konstruk atau variabel dapat dikatakan reliabel jika memberikan nilai cronbach alpha $>0,60$ (Ghozali, 2011:42). Hasil Uji Reabilitias nilai Cronbach alpha dapat dilihat pada Lampiran 2. Dari hasil uji tersebut terlihat nilai cronbach's alpha dari masing-masing variabel dalam penelitian ini lebih besar 0,60 yang berarti butir-butir pernyataan dari seluruh variabel Kompetensi, Budaya Kerja, Person Job Fit, dan Kinerja Karyawan seluruhnya reliabel dan dapat digunakan dalam penelitian.

\section{Evaluasi Model Pengukuran (Outer Model)}

Berdasarkan sajian data dalam Lampiran 3 diketahui bahwa masing-masing indikator variabel penelitian banyak yang memiliki nilai outer loading $>0,7$. Namun, terlihat masih terdapat beberapa indikator yang memiliki nilai outer loading $<0,7$. Menurut Chin (dalam Ghozali, 2014) nilai outer loading antara 0,5-0,6 sudah dianggap cukup untuk memenuhi syarat convergent validity. Data di tabel 14 menunjukkan terdapat 1 indikator yaitu BK3 pada variabel Budaya Kerja yang nilai outer loadingnya dibawah 0,5 sehingga dua indikator tersebut dianggap tidak layak atau tidak valid digunakan. Selain indikator BK3 dinyatakan layak atau valid untuk digunakan penelitian dan dapat digunakan untuk analisis lebih lanjut.

\section{Discriminant Validity}

Berdasarkan sajian data dalam Lampiran 4, diketahui bahwa nilai AVE variabel kompetensi, budaya kerja, person job fit, dan kinerja karyawan $>0,5$. Maka dapat dinyatakan bahwa setiap variabel telah memiliki discriminant validity yang baik.

\section{Composite Reliability}

Composite Realibility merupakan bagian yang digunakan untuk menguji nilai reliabilitas indikatorindikator pada suatu variabel. Suatu variabel dapat dinyatakan memenuhi composite reliabilAity apabila memiliki nilai composite reliability $>0,6$ Nilai composite reliability dari masing-masing variabel dapat dilihat di Lampiran 5. Berdasarkan sajian data pada tabel 6, dapat diketahui bahwa nilai composite reliability semua variabel penelitian $>0,6$. Hasil ini menunjukkan bahwa masing-masing variabel telah memenuhi composite reliability sehingga dapat disimpulkan bahwa keseluruhan variabel memenuhi tingkat reliabilitas yang tinggi. 


\section{Cronbach Alpha}

Uji reliabilitas dengan composite reliability dapat diperkuat dengan menggunakan nilai Cronbach alpha. Suatu variabel dapat dinyatkaan reliabel atau memenuhi Cronbach alpha apabila memilki nilai Cronbach alpha $>0,7$. Nilai Cronbach alpha dari masing-masing variable dapat dilihat di Lampiran 6. dapat diketahui bahwa nilai Cronbach alpha dari masing-masing variabel penelitian $>0.7$. Hasil ini menunjukkan bahwa masing-masing variabel penelitian telah memenuhi persyaratan nilai Cronbach alpha sehingga dapat disimpulkan bahwa keseluruhan variabel memiliki tingkat reliabilitas yang tinggi.

\section{Evaluasi Model Pengukuran (Inner Model)}

Berdasarkan pengolahan data yang telah dilakukan dengan menggunakan program smartPLS 3.0 diperoleh nilai $R$-Square seperti yang dapat dilihat di tabel 2 . Nilai R-Square untuk variabel Person Job Fit adalah 0.452. Perolehan nilai tersebut menjelaskan bahwa presentase besarnya Person Job Fit dapat di jelaskan oleh kompetensi dan budaya kerja sebear 45,2\%. Kemudian untuk nilai R-Square yang diperoleh variabel Kinerja Karyawan sebesar 0.726. Nilai tersebut menjelasakan bahwa kinerja karyawan dapat dijelaskan oleh kompetensi, budaya kerja, dan person job fit sebesar $72.6 \%$.

Tabel 2.

NILAI R-SQUARE

\begin{tabular}{lc}
\hline Variabel & R-Square \\
\hline Person Job Fit & 0.452 \\
\hline Kinerja Karyawan & 0.726 \\
\hline \multicolumn{2}{l}{ Sumber : Output SmartPLS 3.0}
\end{tabular}

\section{Uji Hipotesis}

Berdasarkan olah data yang telah dilakukan, hasilnya dapat digunakan untuk menjawab hipotesis pada penelitian ini. Uji hipotesis pada penelitian ini dilakukan dengan melihat nilai $T$-Statistics dan nilai $P$ Values. Hipotesis penelitian dapat dinyatakan diterima apabila nilai $P$-Values $<0,05$. Hasil uji hipotesis yang diperoleh dalam penelitian ini melalui inner model seperti dalam tabel 9. Berdasarkan sajian data pada tabel 3, dapat diketahui bahwa dari lima hipotesis yang diajukan dalam penelitian ini terdapat 2 hipotesa yang ditolak karena memiliki nilai P-Values $>0,05$ sehingga dapat dinyatakan variabel independen ke dependennya memiliki pengaruh yang tidak signifikan. Tiga hipotesa lainnya dapat diterima karena masing-masing pengaruh yang ditunjukkan memiliki nilai P-Values $<0,05$ sehingga dapat dinyatakan variabel independen ke dependennya memiliki pengaruh yang signifikan. Diagram hasil uji hipotesis dapat dilihat di Gambar 2.

Tabel 3.

\section{T-STATISTICS DAN P-VALUES}

\begin{tabular}{|c|c|c|c|c|}
\hline Hipotesis & Pengaruh & T-Statistics & P-Values & Hasil \\
\hline $\mathrm{H} 1$ & $\begin{array}{l}\text { Kompetensi } \rightarrow \\
\text { Person Job Fit }\end{array}$ & 1.737 & 0.083 & Ditolak \\
\hline $\mathrm{H} 2$ & $\begin{array}{l}\text { Budaya Kerja } \\
\rightarrow \text { Person Job } \\
\text { Fit }\end{array}$ & 3.478 & 0.001 & Diterima \\
\hline $\mathrm{H} 3$ & $\begin{array}{l}\text { Kompetensi } \rightarrow \\
\text { Kinerja } \\
\text { Karyawan }\end{array}$ & 1.051 & 0.294 & Ditolak \\
\hline $\mathrm{H} 4$ & $\begin{array}{l}\text { Budaya } \quad \text { Kerja } \\
\rightarrow \quad \text { Kinerja } \\
\text { Karyawan }\end{array}$ & 2.400 & 0.017 & Diterima \\
\hline $\mathrm{H} 5$ & $\begin{array}{l}\text { Person Job Fit } \\
\rightarrow \quad \text { Kinerja } \\
\text { Karyawan }\end{array}$ & 3.673 & 0.000 & Diterima \\
\hline
\end{tabular}


Lutfiyah, Hening Widi Oetomo, Suhermin. Pengaruh Kompetensi dan Budaya Kerja terhadap Person Job Fit dan Kinerja Karyawan pada PT Andromedia

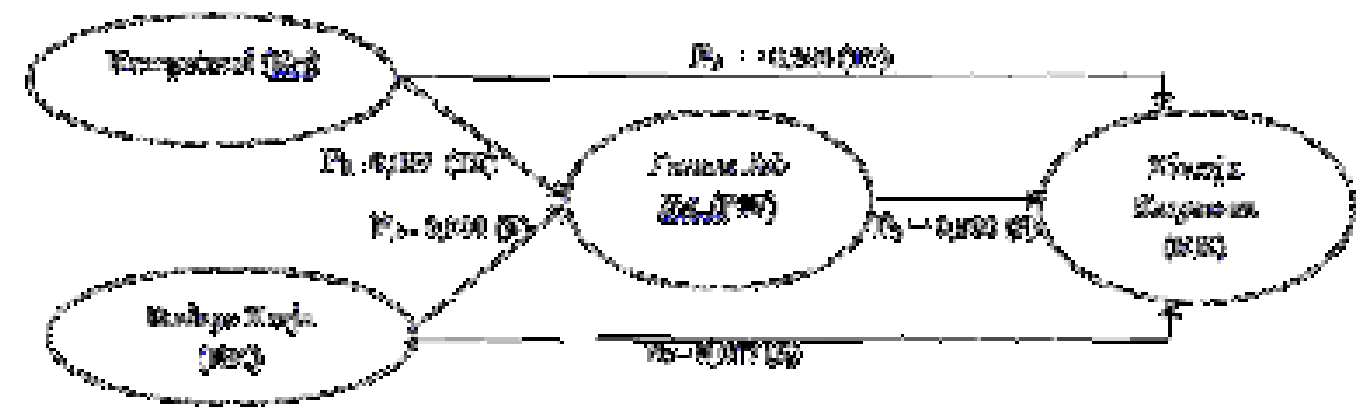

Gambar 2. ANALISIS JALUR (PATH ANALYSIS)

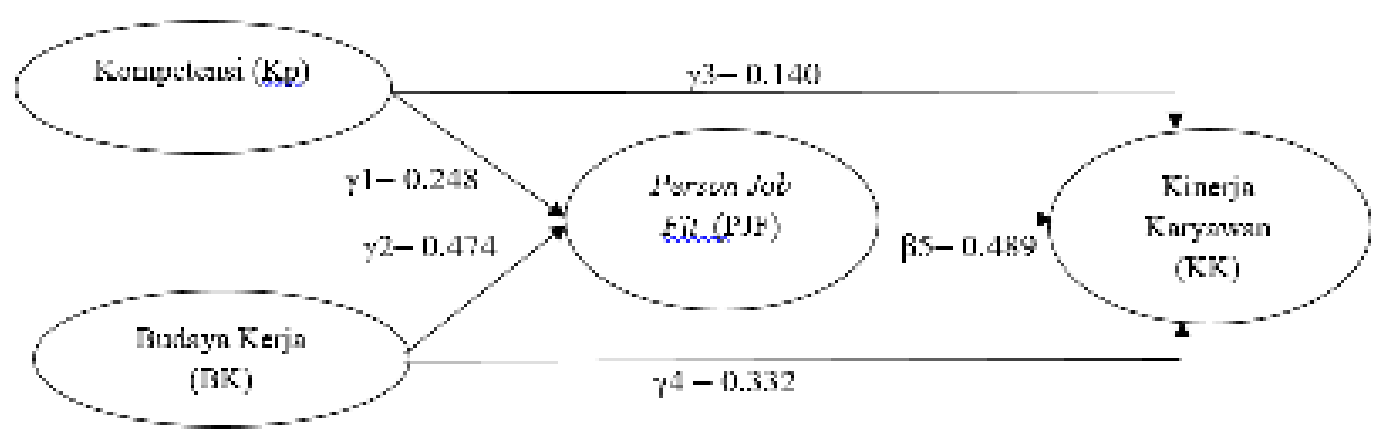

Gambar 3. PATH COEFFICIENT

Gambar 3 menjelaskan bahwa spesifikasi hubungan antar variabel laten (structural model), disebut juga dengan inner relation yang menggambarkan hubungan antar variabel laten berdasarkan teori substansif penelitian. Tanpa kehilangan sifat umumnya, diasumsikan bahwa variabel laten dan indikator atau variabel manifest di skala zero means dan unit varian sama dengan satu, sehingga parameter lokasi (parameter konstanta) dapat dihilangkan dari model. Model persamaannya dapat ditulis sesuai rumus (1) dan (2).

$\mathrm{PJF}=0.248 \mathrm{Kp}+0.473 \mathrm{BK}$

$\mathrm{KK}=0.140 \mathrm{Kp}+0.332 \mathrm{BK}+0.489 \mathrm{PJF}$

Berdasarkan persamaan tersebut dapat dinyatakan spesifikasi hubungan antar variabel laten mempunyai nilai positif. Sehingga dapat disimpulkan hubungan antar variabel eksogen terhadap variabel endogen selain mempunyai pengaruh signifikan atau tidak signifikan, juga positif.

\section{Pengaruh Kompetensi terhadap Person Job Fit}

Hasil pengujian menunjukkan Kompetensi berpengaruh positif dan tidak signifikan terhadap Person Job Fit. Hasil ini mencerminkan bahwa semakin tinggi Kompetensi yang dimiliki karyawan PT Andromedia maka memiliki pengaruh kecil yang tidak signifikan terhadap Person Job Fit karyawan PT Andromedia. Hal ini dikarenakan pada PT Andromedia merupakan perusahaan yang bergerak di bidang Development IT yang mana perkembangan teknologi yang semakin canggih mengharuskan karyawan untuk berkompeten dan dapat menyesuaikan kecocokan dirinya dengan tim kerja (Person job fit) sesuai beban pekerjaan yang akan dikerjakan.

Hasil penelitian ini tidak sejalan dengan pendapat dari Widyaastuti dan Ratnaningsih (2018) menjelaskan adanya hubungan kompetensi dan person job fit dilihat dari aspek pendidikan. Dikarenakan dalam pengujian hubungan kompetensi dan person job fit tidak hanya dilihat dari aspek pendidikan tetapi terdapat indikator lain antara lain minat, pengalaman kerja, kemampuan fisik dan intelektual.

\section{Pengaruh Budaya Kerja terhadap Person Job Fit}

Hasil pengujian menunjukkan Budaya Kerja berpengaruh positif dan signifikan terhadap Person Job Fit. Hasil ini mencerminkan bahwa semakin tinggi Budaya Kerja yang dimiliki karyawan PT 
Andromedia maka memiliki pengaruh yang signifikan terhadap Person Job Fit karyawan PT Andromedia. Budaya kerja diterapkan pada PT Andromedia di mana setiap proyek yang dikerjakan merupakan kerja tim yang dilakukan oleh beberapa karyawan. Oleh sebab itu karyawan pada PT Andromedia diharapkan siap untuk bekerja sama atau menyesuaikan diri antar individual pada pekerjaan.

Karyawan PT Andromedia memiliki penilaian yang sangat baik atau sangat setuju terhadap pernyataan dari indikator-indikator Budaya Kerja dan Person Job Fit. Hasil penelitian ini sejalan dengan Pendapat dari Supriyadi dan Guno (2011:7) mengemukakan bahwa budaya kerja adalah suatu falsafah dengan didasari pandangan hidup sebagai nilai-nilai yang menjadi sifat, kebiasaan dan juga pendorong yang dibudayakan dalam suatu kelompok. Selain itu juga sejalan dengan pendapat lain dari Ozag dan Duguma (2005) yang menjelaskan dalam teori person job fit adanya kesesuaian antara karakteristik tugas pekerjaan dengan kebutuhan individu untuk melaksanakan tugas tersebut, akan memperkuat ikatan pegawai pada kerja yaitu pegawai akan lebih komitmen terhadap pekerjaan sehingga kenyamanaan pada diri karyawan itu muncul. Kenyamanan kerja karyawan dipengaruhi oleh faktor kenyamanan seorang individu tersebut terhadap budaya kerja yang ada di dalam suatu perusahaan.

\section{Pengaruh Kompetensi terhadap Kinerja Karyawan}

Hasil pengujian menunjukkan Kompetensi berpengaruh positif dan signifikan terhadap Kinerja Karyawan. Hasil ini mencerminkan bahwa semakin tinggi Kompetensi yang dimiliki karyawan PT Andromedia maka memiliki pengaruh kecil yang tidak signifikan terhadap Kinerja karyawan PT Andromedia. Hal ini dapat menguatkan informasi dari HRD pada PT Andromedia yang mengasumsikan bahwasannya terdapat gap antara kemampuan kompetensi yang dimiliki oleh karyawan dengan kinerja yang dihasilkan berdasarkan data jumlah karyawan dan penyelesaian project pada PT Andromedia tahun 2017. Namun kemungkinan tersebut tidak dapat dijadikan alasan khusus karena setiap karyawan harus siap bekerja dibawah tekanan.

Karyawan PT Andromedia memiliki penilaian yang sangat baik atau sangat setuju terhadap pernyataan dari indikator-indikator Kompetensi dan Kinerja Karyawan. Hasil penelitian ini tidak sejalan dengan penelitian dari Suliman (2011) dan Abila (2015) yang menunjukkan bahwa kompetensi memiliki pengaruh yang signifikan dan positif terhadap kinerja karyawan. Berbeda dengan hasil penelitian Widyasmoko (dalam Rahayuningsih dan Maelani, 2017) senada dengan penelitian ini yang menunjukkan bahwa kompetensi berpengaruh tidak signifikan terhadap kinerja karyawan.

\section{Pengaruh Budaya Kerja terhadap Kinerja Karyawan}

Hasil pengujian menunjukkan Budaya Kerja berpengaruh positif dan signifikan terhadap Kinerja Karyawan. Hasil ini dapat diartikan bahwa semakin tinggi Budaya Kerja yang dimiliki karyawan PT Andromedia maka memiliki pengaruh yang signifikan terhadap Kinerja karyawan PT Andromedia. Karyawan pada PT Andromedia harus mampu beradaptasi dengan budaya selain berkompeten, di mana setiap proyek yang dikerjakan merupakan kerja tim yang dilakukan oleh beberapa karyawan yang membentuk budaya kerja yang positif dan energik dengan saling memberikan semangat di tempat kerja.

Karyawan PT Andromedia memiliki penilaian yang sangat baik atau sangat setuju terhadap pernyataan dari indikator-indikator Budaya Kerja dan Kinerja Karyawan. Hasil penelitian ini sejalan dengan penelitian dari Safrizal et al (2014), Jamaluddin et al (2017), dan Silvia et al (2016) yang menunjukkan bahwa budaya kerja berpengaruh signifikan terhadap kinerja karyawan. Berbeda tidak sejalan dengan hasil penelitian Arifin (2010) menunjukkan bahawa budaya kerja berpengaruh tidak signifikan terhadap kinerja karyawan.

\section{Pengaruh Person Job Fit terhadap Kinerja Karyawan}

Hasil pengujian menunjukkan Person Job Fit berpengaruh positif dan signifikan terhadap Kinerja Karyawan. Hasil ini dapat diartikan bahwa semakin baik Person Job Fit yang dimiliki karyawan PT Andromedia maka memiliki pengaruh yang signifikan terhadap Kinerja karyawan PT Andromedia. Cocoknya kemampuan dari individu dengan tuntutan dari sebuah pekerjaan, sama halnya yang ada pada 
Lutfiyah, Hening Widi Oetomo, Suhermin. Pengaruh Kompetensi dan Budaya Kerja terhadap Person Job Fit dan Kinerja Karyawan pada PT Andromedia

PT Andromedia di mana project yang dikerjakan disesuaikan dengan kemampuan dari diri kayawan untuk menghasilkan kinerja yang baik.

Karyawan PT Andromedia memiliki penilaian yang sangat baik atau sangat setuju terhadap pernyataan dari indikator-indikator Peson Job Fit dan Kinerja Karyawan. Hasil penelitian ini sejalan dengan penelitian June et al (2013) dan Wahjudhy (2014) menjelaskan bahwasannya person job fit berpengaruh positif dan signifikan terhadap kinerja karyawan.

\section{Peranan Person Job Fit Sebagai Intervening}

Variabel penelitian ini terdiri dari variabel eksogen, variabel antara (Intervening) dan variabel endogen yang masing-masing memiliki hubungan sebab-akibat. Variabel bebas yang akan digunakan dalam penelitian ini adalah Kompetensi dan Budaya Kerja. Sedangkan variabel antara yaitu Person Job Fit dan variabel terikat yaitu Kinerja Karyawan.

Berdasarkan hasil analisis pengaruh tidak langsung kompetensi terhadap kinerja karyawan melalui person job fit adalah tidak signifikan dan pengaruh langsung kompetensi terhadap kinerja karyawan juga tidak signifikan, maka dapat disimpulkan bahwa peranan person job fit bukan termasuk Intervening atau tidak memediasi pengaruh kompetensi terhadap kinerja karyawan.

Secara praktis pernyataan tersebut dapat menguatkan informasi dari HRD pada PT Andromedia yang mengasumsikan bahwasannya terdapat gap antara kemampuan kompetensi yang dimiliki oleh karyawan dengan kinerja yang dihasilkan berdasarkan data jumlah karyawan dan penyelesaian project pada PT Andromedia tahun 2017. Namun kemungkinan tersebut tidak dapat dijadikan alasan khusus karena setiap karyawan harus siap bekerja dibawah tekanan.

Berdasarkan kriteria pengujian Intervening parsial, menurut Suliyanto (2011) variabel $M$ dinyatakan sebagai variabel parsial (partial mediation) jika setelah memasukkan varial $M$, pengaruh variabel $X$ terhadapa variabel $Y$ yang tadinya signifikan (sebelum memasukkan variabel $M$ ) menjadi tetap signifikan setelah memasukkan variabel $M$ ke dalam model persaman regresi. Hasil analisis pengaruh tidak langsung budaya kerja terhadap kinerja karyawan melalui person job fit adalah signifikan dan pengaruh langsung kompetensi terhadap kinerja karyawan juga signifikan, maka dapat disimpulkan bahwa peranan person job fit sebagai Intervening parsial atau semu sehigga dapat dikatakan person job fit memediasi pengaruh budaya terhadap kinerja karyawan.

Secara praktis pernyataan tersebut sama dengan Budaya kerja yang diterapkan pada PT Andromedia di mana setiap proyek yang dikerjakan merupakan kerja tim yang dilakukan oleh beberapa karyawan. Karyawan pada PT Andromedia harus mampu beradaptasi dengan budaya selain berkompeten, di mana setiap proyek yang dikerjakan merupakan kerja tim yang dilakukan oleh beberapa karyawan yang membentuk budaya kerja yang positif dan energik dengan saling memberikan semangat di tempat kerja. Oleh sebab itu karyawan pada PT Andromedia diharapkan siap untuk bekerja sama atau menyesuaikan diri antar individual pada pekerjaan.

\section{KESIMPULAN}

Kompetensi tidak terbukti berpengaruh terhadap Person Job Fit pada PT Andromedia. Hasil ini mencerminkan bahwa semakin tinggi Kompetensi yang dimiliki karyawan PT Andromedia maka memiliki pengaruh kecil yang tidak signifikan terhadap Person Job Fit karyawan PT Andromedia. Budaya Kerja berpengaruh positif dan signifikan terhadap Person Job Fit pada PT Andromedia. Hasil ini mencerminkan bahwa semakin tinggi Budaya Kerja yang dimiliki karyawan PT Andromedia maka memiliki pengaruh yang signifikan terhadap Person Job Fit karyawan PT Andromedia. Kompetensi tidak terbukti berpengaruh terhadap Kinerja Karyawan pada PT Andromedia. Hasil ini mencerminkan bahwa semakin tinggi Kompetensi yang dimiliki karyawan PT Andromedia maka memiliki pengaruh kecil yang tidak signifikan terhadap Kinerja karyawan PT Andromedia. Budaya Kerja berpengaruh positif dan signifikan terhadap Kinerja Karyawan pada PT Andromedia. Hasil ini dapat diartikan bahwa semakin tinggi Budaya Kerja yang dimiliki karyawan PT Andromedia maka memiliki pengaruh yang 
signifikan terhadap Kinerja karyawan PT Andromedia. Person Job Fit berpengaruh positif dan signifikan terhadap Kinerja Karyawan pada PT Andromedia. Hasil ini dapat diartikan bahwa semakin baik Person Job Fit yang dimiliki karyawan PT Andromedia maka memiliki pengaruh yang signifikan terhadap Kinerja karyawan PT Andromedia.

Impikasinya, peranan Person Job Fit memediasi pengaruh budaya kerja terhadap kinerja karyawan. Oleh sebab itu karyawan harus siap untuk bekerja sama dan menyesuaikan diri antar individual pada pekerjaan. Secara umum kinerja dapat ditingkatkan dengan mengelola potensi masing-masing karyawan dengan sebaik-baiknya. Karyawan harus diberi ruang dan kesempatan untuk berprestasi dan berkinerja lebih optimal. Secara teoritis, teori kompetensi dalam penelitian ini masih belum mampu meningkatkan kinerja karyawan PT Andromedia. Sebagai acuan dari penelitian Suliman (2011) dan Abila (2015), hal ini dibuktikan dengan perbandingan variabel lainnya pada penelitian dalam meningkatkan kinerja karyawan. Penelitian selanjutnya disarankan menguji variabel Person Job Fit sebagai variabel mediasi antara kompetensi dan budaya kerja terhadap kinerja karyawan dengan studi kasus perusahaan yang bergerak pada bidang industri Non-IT.

\section{DAFTAR PUSTAKA}

Abila, B. (2015). Pengaruh Kompetensi dan Person Job Fit Terhadap Job Performance pada karyawan PT Dentsu. Jurnal Binus University. 1(1).

Cable, D.M. dan D.S. DeRue. (2002). The Convergent dan Discriminant Validity of Subjective Fit Perceptions. Journal of Applied Psychology. 87(5):875-884.

Christiansen, D., Sliter, M. T., dan Frost C. T. (2014). What employees dislike about their jobs: relationship between personality-based fit and work satisfaction. Personality and Individual Differences. 7(1):25-29.

Fahmi, I. (2014). Perilaku Organisasi: Teori, Aplikasi, dan Kasus. Cetakan Kedua. CV. Alfabeta. Anggota IKAPI. Bandung.

Farzaneh, J., A.D. Farashah. dan M. Kazemi. (2014). The impact of person-job fit and personorganization fit on OCB. Personnel Review. 43(5):672-691.

Frinaldi, A. (2014). Konflik Dan Pengaruh Budaya Kerja Etnik Dalam Kalangan Kakitangan Awam Di Pihak Berkuasa Tempatan Pasaman Barat, Wilayah Sumatera Barat, Indonesia. Disertasi Doktor Falsafah Universiti Utara. Malaysia.

Ghozali, I. (2014). Structural Equation Modeling Metode Alternatif dengan Partial Least Square. Badan Penerbit Universitas Diponegoro. Semarang.

Huang, H. (2015). Olah data SEM dengan LISREL, AMOS atau SMART PLS. https://www.en.globalstatistik.com/jasa-olah-data-sem-dengan-amos-lisrel-atau-pls/ (diakses tanggl 1 Mei 2020)

Jamaluddin, R. Salam, H. Yunus. Dan H. Akib. (2017). Pengaruh Budaya Organisasi terhadap Kinerja Pegawai pada Dinas Pendidikan Provinsi Sulawesi Selatan. Jurnal Pemikiran ilmiah dan pendidikan administrasi perkantoran. 4(1).

June. S., Y.K.Kheng, dan R.Mahmood. (2013). Determining the Importance of Competency and Person-Job Fit for the Job Performance of Service SMEs Employees in Malaysia. Canadian Center of Science and Education. 9(10).

Kasmir. (2016). Manajemen Sumber Daya Manusia (Teori dan Praktek). Raja Grafindo Persada. Jakarta. 
Lutfiyah, Hening Widi Oetomo, Suhermin. Pengaruh Kompetensi dan Budaya Kerja terhadap Person Job Fit dan Kinerja Karyawan pada PT Andromedia

Kristof-Brown, A.L., R.D.Zimmerman, dan E.C. Johnson. (2005). Consequences of Individuals Fit at Work: A Meta-Analysis of Person-Job, PersonOrganization, Person-Group, dan PersonSupervisor Fit. Personnel Psychology. 58(2):281-432.

Lolowang, L.N., Troena, A.E., A.Djazuli dan S. Aisya. (2019). The effect of leadership and organizational culture on employee performance that is educated by motivation (study on the implementation empowerment programs in Jayapura city). Problems and Perspectives in Management. 17(1), 268-277.

Mahdi, A. F., Zin, M. Z., Nor, M. R., Sakat, A. A., dan Naim, A. S. (2012). The relationship between job satisfaction and turnover intention. American Journal of Applied Science. 9(9):1518-1526.

Mangkunegara, A.A.A P. (2014). Manajemen Sumber Daya Manusia Perusahaan Jilid 1. PT Remaja Rosdakarya. Bandung.

Mangkunegara, P.A., dan A. Waris. (2015). Effect of Training, Competence and Discipline on Employee Performance in Company (Case Studi in PT Asuransi Bangun Askrida). ProcediaSocial and Behavioral Sciencess. 221(1):1240-1251.

Moeheriono. (2014). Pengukuran Kinerja Berbasis Kompetensi, Edisi Revisi. Rajawali Pers. Jakarta

Nurhadijah. (2017). Studi tentang Budaya Kerja Pegawai Sekolah Menengah Kejuruan Negeri 1 Penajam Paser Utara. ejournal Administrasi Negara. 5(1):4.

Pramudyo, A. (2010). Analisis Faktor-faktor yang Memengaruhi Kinerja Dosen Negeri Dipekerjakan Pada Kopertis Wilayah V Yogyakarta. JBTI Yogyakarta. 1(1).

Prayitno D.J, dan Andrilina T. (2015). Kompetensi dan Manajemen Sumber Daya Manusia. (http://bumn.go.id/ptpn5/berita/0-Kompetensi-dan-Manajemen-Sumber-Daya-Manusia, diakses tanggl 2 Januari 2019).

Priansa, D.J. (2014). Perencanaan \& Pengembangan SDM. Penerbit Alfabeta. Bandung.

Rahayuningsih S, dan N. Maelani. (2017). Pengaruh Kompetensi, Kompensasi Dan Pengembangan Karier Terhadap Kinerja Karyawan (Studi Pada PT. Aquafarm Nusantara Semarang). Jurnal Universitas Stikubank Semarang. 1(1).

Robbin, S.P, dan T.A. Judge. (2008). Perilaku Organisasi, Buku 1. Salemba Empat Hal 256. Jakarta.

Rogelberg, S.G. (2012). Encyclopedia of Industrial and Organizational Psychology. Sage Publication. London.

Safrizal., M.Said, dan C.Syafruddin. (2014) Pengaruh Budaya Kerja, Kemampuan dan Komitemen Pegawai Terhadap Kinerja Pegawai Serta Dampaknya Pada Kinerja Dinas Pertambangan dan Energi Aceh. Jurnal Manajemen Pascasarjana Universitas Syiah Kuala. 1(1):44-53

Silvia., I.W. Bagia, dan W. Cipta. (2016). Pengaruh Kompetensi Dan Budaya Kerja Terhadap Kinerja Karyawan. e-Journal Bisma Universitas Pendidikan Ganesha Jurusan Manajemen. 4(1).

Suliman, M. (2011). Analisis Person-Job-Fit Dan Kompetensi Pengaruhnya Terhadap Kinerja Karyawan Pada PT. Atri Distribusindo Bandung. Program Pasca Sarjana Universitas Komputer Indonesia. Bandung

Suliyanto. (2011). Ekonometrika Terapan Teori dan Aplikasi dengan SPSS. Penerbit CV.Andi Offiset. Yogyakarta. 
Sugiyono. (2017). Metode Penelitian Kuantitatif, Kualitatif, dan R\&D. Alfabeta. Bandung.

Supriyadi G, dan Guno T. (2011). Budaya Kerja Organisasi Pemerintah. Lembaga Administrasi Negara RI. Jakarta.

Sysindo. (2018). Pentingnya Kinerja Karyawan di Perusahaan. https://sysindokonsultan.com/newsartikel/pentingnya-kinerja-karyawan-di-perusahaan (diakses tanggl 2 Januari 2019)

Tridharma K. (2017). Pentingnya Budaya Kerja di Perusahaan. (https://www.tdk.co.id/index.php?page=read-perspektif\&id=3, diakses tanggl 2 Januari 2019)

Yamin, S dan H. Kurniawan, (2011). Partial Least Square Path Modeling. Salemba Infotek.

Wahjudhy, I. (2014). Analisis Pengaruh Person-Jon Fit dan Kepuasan kerja Terhadap Kinerja Karyawan Pada CV Pion Pring. Jurnal Binus University. 1(1).

Wibowo. (2016). Manajemen Kinerja, Edisi Kelima. PT Raja Grafindo Persada. Jakarta.

Widyaastuti, T dan I.Z. Ratnaningsih. (2018). Hubungan Antara Person Job-Fit Dengan Kepuasan Kerja Pada Karyawan Kantor Pusat Bank Jateng Semarang. Jurnal Empati. 7(3):73-79.

\section{Lampiran 1. HASIL UJI VALIDITAS}

\begin{tabular}{|c|c|c|c|c|}
\hline Variabel & Indikator & Corrected Item-total Correlation (R Hitung) & rtabel & Keterangan \\
\hline \multirow{5}{*}{ Kompetensi (Kp) } & $\mathrm{Kp}_{1}$ & 0.254 & 0,196 & Valid \\
\hline & $\mathrm{Kp}_{2}$ & 0.746 & 0,196 & Valid \\
\hline & $\mathrm{Kp}_{3}$ & 0.798 & 0,196 & Valid \\
\hline & $\mathrm{Kp}_{4}$ & 0.902 & 0,196 & Valid \\
\hline & $\mathrm{Kp}_{5}$ & 0.586 & 0,196 & Valid \\
\hline \multirow{12}{*}{ Budaya Kerja (BK) } & $\mathrm{BK}_{1}$ & 0.818 & 0,196 & Valid \\
\hline & $\mathrm{BK}_{2}$ & 0.802 & 0,196 & Valid \\
\hline & $\mathrm{BK}_{3}$ & 0.459 & 0,196 & Valid \\
\hline & $\mathrm{BK}_{4}$ & 0.794 & 0,196 & Valid \\
\hline & $\mathrm{BK}_{5}$ & 0.831 & 0,196 & Valid \\
\hline & $\mathrm{BK}_{6}$ & 0.843 & 0,196 & Valid \\
\hline & $\mathrm{BK}_{7}$ & 0.850 & 0,196 & Valid \\
\hline & $\mathrm{BK}_{8}$ & 0.843 & 0,196 & Valid \\
\hline & $\mathrm{BK}_{9}$ & 0.700 & 0,196 & Valid \\
\hline & $\mathrm{BK}_{10}$ & 0.745 & 0,196 & Valid \\
\hline & $\mathrm{BK}_{11}$ & 0.710 & 0,196 & Valid \\
\hline & $\mathrm{BK}_{12}$ & 0.857 & 0,196 & Valid \\
\hline \multirow[t]{4}{*}{ Person Job Fit (PJF) } & $\mathrm{PJF}_{1}$ & 0.887 & 0,196 & Valid \\
\hline & $\mathrm{PJF}_{2}$ & 0.928 & 0,196 & Valid \\
\hline & $\mathrm{PJF}_{3}$ & 0.814 & 0,196 & Valid \\
\hline & $\mathrm{PJF}_{4}$ & 0.934 & 0,196 & Valid \\
\hline \multirow[t]{8}{*}{ Kinerja Karyawan } & $\mathrm{KK}_{1}$ & 0.553 & 0,196 & Valid \\
\hline & $\mathrm{KK}_{2}$ & 0.796 & 0,196 & Valid \\
\hline & $\mathrm{KK}_{3}$ & 0.749 & 0,196 & Valid \\
\hline & $\mathrm{KK}_{4}$ & 0.779 & 0,196 & Valid \\
\hline & $\mathrm{KK}_{5}$ & 0.873 & 0,196 & Valid \\
\hline & $\mathrm{KK}_{6}$ & 0.694 & 0,196 & Valid \\
\hline & $\mathrm{KK}_{7}$ & 0.808 & 0,196 & Valid \\
\hline & $\mathrm{KK}_{8}$ & 0.720 & 0,196 & Valid \\
\hline
\end{tabular}

Sumber : Output SmartPLS 3.0 
Lutfiyah, Hening Widi Oetomo, Suhermin. Pengaruh Kompetensi dan Budaya Kerja terhadap Person Job Fit dan Kinerja Karyawan pada PT Andromedia

\section{Lampiran 2. HASIL UJI RELIABILITAS}

\begin{tabular}{lll}
\hline Keterangan & Cronbach Alpha & N of Items \\
\hline Kompetensi & 0.712 & 5 \\
Budaya Kerja & 0.938 & 12 \\
Person Job Fit & 0.914 & 4 \\
Kinerja Karyawan & 0.887 & 8 \\
\hline
\end{tabular}

Sumber : Output SmartPLS 3.0

\section{Lampiran 3. OUTER LOADING}

\begin{tabular}{|c|c|c|}
\hline Variabel & Indikator & Outer Loading \\
\hline \multirow[t]{5}{*}{ Kompetensi } & KP1 & 0.551 \\
\hline & KP2 & 0.758 \\
\hline & KP3 & 0.796 \\
\hline & KP4 & 0.868 \\
\hline & KP5 & 0.737 \\
\hline \multirow[t]{12}{*}{ Budaya Kerja } & BK1 & 0.814 \\
\hline & BK2 & 0.803 \\
\hline & BK3 & 0.466 \\
\hline & BK4 & 0.838 \\
\hline & BK5 & 0.862 \\
\hline & BK6 & 0.868 \\
\hline & BK7 & 0.863 \\
\hline & BK8 & 0.896 \\
\hline & BK9 & 0.780 \\
\hline & BK10 & 0.789 \\
\hline & BK11 & 0.817 \\
\hline & BK12 & 0.873 \\
\hline \multirow[t]{4}{*}{ Person Job Fit } & PJF1 & 0.905 \\
\hline & PJF2 & 0.919 \\
\hline & PJF3 & 0.863 \\
\hline & PJF4 & 0.931 \\
\hline \multirow[t]{8}{*}{ Kinerja Karyawan } & KK1 & 0.687 \\
\hline & KK2 & 0.826 \\
\hline & KK3 & 0.805 \\
\hline & KK4 & 0.834 \\
\hline & KK5 & 0.907 \\
\hline & KK6 & 0.827 \\
\hline & KK7 & 0.847 \\
\hline & KK8 & 0.831 \\
\hline
\end{tabular}

Sumber : Output SmartPLS 3.0

Lampiran 4. AVERAGE VARIANT EXTRACTED (AVE)

\begin{tabular}{ll}
\hline \multicolumn{1}{c}{ Variabel } & AVE \\
\hline Kompetensi & 0.562 \\
\hline Budaya Kerja & 0.661 \\
\hline Person Job Fit & 0.818 \\
\hline Kinerja Karyawan & 0.677 \\
\hline
\end{tabular}

Sumber : Output SmartPLS 3.0 


\section{Lampiran 5. COMPOSITE RELIABILITY}

\begin{tabular}{lc}
\hline Variabel & Composite Reliability \\
\hline Kompetensi & 0.863 \\
\hline Budaya Kerja & 0.958 \\
\hline Person Job Fit & 0.947 \\
\hline Kinerja Karyawan & 0.943 \\
\hline Sumber : Output SmartPLS 3.0
\end{tabular}

Lampiran 6. CRONBACH ALPHA

\begin{tabular}{lc}
\hline Variabel & Cronbach Alpha \\
\hline Kompetensi & 0.802 \\
\hline Budaya Kerja & 0.951 \\
\hline Person Job Fit & 0.926 \\
\hline Kinerja Karyawan & 0.931 \\
\hline Sumber : Output SmartPLS 3.0
\end{tabular}

Sumber : Output SmartPLS 3.0 